\title{
INFLUENCE OF DIETARY PROTEIN CONTENT ON Trypanosoma cruzi INFECTION IN GERMFREE AND CONVENTIONAL MICE
}

Isa P. CINTRA (1), Marcelo E. SILVA (1), Marcílio E.C. SILVA, Márcio E. SILVA, L.C. C. AFONSO (2), Jacques R. NICOLI (3), Eduardo A. BAMBIRRA (4) \& Enio C. VIEIRA

\section{SUMMARY}

Germfree (GF) and conventional (CV) mice were fed on diets containing 4.4, 13.2 or $26.4 \%$ of protein (weight/weight). $\mathrm{CV}$ mice fed on low protein diet did not gain weight during four weeks, whereas the protein deficient diet did not affect the growth of GF mice. After four weeks on these diets, the mice were inoculated with $5 \times 10^{3}$ trypomastigotes of Trypanosoma cruzi. The protein deficiency affected less the GF than the CV mice, according to the following parameters: weight gain, hemoglobin, plasma protein and albumin levels and water and protein contents of the carcass. Infection with $T$. cruzi produced a significant decrease in hemoglobin levels, red blood cell count, and water and protein contents in the carcass. This decrease was more pronounced in the GF mice. Histopathologically, there was no difference between the treatments in animals with the same microbiological status (GF or CV). However, the disease was more severe in the GF than in the CV mice.

KEYWORDS: American trypanosomiasis; Gnotobiotic mice: Protein nutriture; Nutrition/infection; Trypanosoma cruzi.

\section{INTRODUCTION}

The host-parasite relationship may be affected by the nutritional status of the former and is dependent upon the pathogen involved and the kind of deficiency to which the host is submitted. In conventional $(\mathrm{CV})$ animals a nutritional insult may either aggravate or ameliorate an infectious disease ${ }^{10}$. American trypanosomiasis was more severe in rats submitted to lysine deficiency than in animals fed on control diet ${ }^{25}$. In addition, CARLOMAGNO et al. showed that protein-energy malnutrition aggravated the trypanosomiasis in mice 4 . More recently, GOMES et al. reported that protein deprivation resulted in higher parasitemia and mortality in mice infected with either Y or CL strains of Trypanosoma cruzi ${ }^{8}$. Protein malnutrition also delays the recovery of noradrenalin levels that normally occurs during the chronic phase of experimental Chagas $^{\prime}$ disease in rats ${ }^{12}$.

In our laboratory, the following observations were made on mice submitted to specific nutritional deficiencies and then infected with T. cruzi: (1) the disease was less severe in germfree (GF) and $\mathrm{CV}$ mice fed on an essential fatty acid deficient diet as compared to controls fed on normal diet ${ }^{18}$; (2) the mortality index was higher in both GF and CV mice either deficient or overloaded with vitamin
E as compared to controls fed on a diet containing normal levels of alpha-tocopherol (ALMEIDA et al., unpublished); (3) the effects of iron nutritional status on the evolution of experimental Chagas' disease in CV mice were not the same for three different strains of T. $\mathrm{cruzi}^{14}$; (4) the parasitemia was more intense in CV and GF mice submitted to an iron overload when compared to that of animals either on normal or on iron depleted diets ${ }^{15}$; (4) vitamin D overload showed a protective effect against the infection in $\mathrm{CV}$ mice ${ }^{20}$.

The GF animal is a good model for studies of host-parasite relationship. The lack of a permanent antigenic challenge by the resident microbiota allows a better assessment of specific responses to any invading agent. American trypanosomiasis is much more severe in GF than in $\mathrm{CV}$ mice and rats $^{19}$; whereas the reverse situation was found for cutaneous leishmaniasis elicited by Leishmania amazonensis, i.e., the disease is much more severe in CV than in GF mice ${ }^{24}$.

In this paper, the evolution of experimental Chagas' disease was studied in GF and CV mice fed on diets containing low, normal or high levels of protein. A preliminary account of the results reported herein was published elsewhere ${ }^{5}$.

(1) Escola de Nutrição, Universidade Federal de Ouro Preto (UFOP), 35400-000 Ouro Preto, MG, Brazil.

(2) Laboratório de Imunoparasitologia, Departamento de Ciências Biológicas / NUPEB, Instituto de Ciências Exatas e Biológicas, UFOP, $35400-000$ Ouro Preto, MG, Brazil.

(3) Laboratório de Ecologia e Fisiologia Microbiana, Departamento de Microbiologia, ICB-UFMG, Caixa Postal 486, $30161-970$ Belo Horizonte, MG, Brazil.

(4) Departamento de Anatomia Patológica, Faculdade de Medicina, UFMG, Caixa Postal 204, 30161-970 Belo Horizonte, MG, Brazil

Correspondence to: Enio C. Vieira, Laboratório de Gnotobiologia e Nutrição, Departamento de Bioquímica e Imunologia, Instituto de Ciências Biológicas, Universidade Federal de Minas Gerais, Caixa Postal 486, 30161-970 Belo Horizonte, MG, Brazil. Phone. 55-31-443-6488, Fax 55-31-441-5963. 
CINTRA, I.P.; SILVA, M.E.; SILVA, M.E.C.; SILVA, M.E.; AFONSO, L.C.C.; NICOLI, J.R.; BAMBIRRA, E.A. \& VIEIRA, E.C. - Influence of dietary protein content on Trypanosoma cruzi infection in germfree and conventional mice. Rev. Inst. Med. trop. S. Paulo, 40 (6): 355-362, 1998.

\section{MATERIAL AND METHODS}

\section{Mice}

CV and GF CFW 21 days old male mice were used. The GF animals were housed in flexible plastic isolators ${ }^{23}$, handled according to established procedures ${ }^{16}$. The animal colony was derived from a breeding nucleus of GF mice kindly supplied by Dr. Morris Pollard (Lobund Laboratory, University of Notre Dame, USA). The CV animals used were derived from the GF colony after many generations in a conventional animal facility.

\section{Diets}

The composition of the diets is shown in Table 1. The diets were prepared in a semi-solid state as described by MORAES-SANTOS et al. ${ }^{13}$.

TABLE 1

Composition of the diets

\begin{tabular}{lccc}
\hline $\begin{array}{l}\text { Ingredients } \\
(\mathbf{g} / \mathbf{1 0 0 g})\end{array}$ & $\begin{array}{c}\text { Hyperproteic } \\
\text { diet }\end{array}$ & $\begin{array}{c}\text { Normoproteic } \\
\text { diet }\end{array}$ & $\begin{array}{c}\text { Hypoproteic } \\
\text { diet }\end{array}$ \\
\hline Casein & 20 & 15 & 5 \\
Salt mixture $^{1}$ & 5 & 5 & 5 \\
Vitamin mixture $^{1}$ & 1 & 1 & 1 \\
Starch $^{2}$ & 54.6 & 69.6 & 79.6 \\
Soy oil $^{2}$ & 8 & 8 & 8 \\
Cellulose & 1 & 1 & 1 \\
Choline chloride & 0.4 & 0.4 & 0.4 \\
kcalories/g & 3.6 & 3.6 & 3.6 \\
\hline
\end{tabular}

AOAC (1980)

${ }^{2}$ Maizena (Refinações de Milho Brasil Ltda.)

\section{Parasites}

T. cruzi, CL strain, isolated by BRENER \& $\mathrm{CHIARI}^{3}$ was maintained by successive transfers in CFW mice. The infection was carried out as described previously ${ }^{19}$.

\section{Parasitemia}

Mice were bled daily from the tail, starting at the 8th day after parasite injection, for the evaluation of the number of circulating parasites, according to BRENER ${ }^{2}$.

\section{Experimental design}

Sixty CV and 60 GF weaning CFW mice were divided in three subgroups, each with 20 animals. Three diets, with protein content of $4.4,13.2$ and $26.4 \%$, were used during the study. The animals were maintained on the diets during all the experimental period.
The mice were weighed weekly. After 28 days on the diet, all animals, except five in each group, were inoculated with $5 \times 10^{3}$ trypomastigotes of T. cruzi, CL strain. Just before inoculation and at the 7 th, 14 th, and 21 st days after inoculation, five mice of each group were sacrificed under ether anesthesia. Blood was drawn from the axillary plexus for determination of hemoglobin, immunoglobulins, plasma protein and albumin levels and numbers of erythrocytes and leukocytes. Liver, heart, kidneys, and spleen were put in $4 \%$ formaldehyde solution for histopathological evaluation. The carcass was used for determination of moisture, protein and ether extract. Parasitemia was determined daily.

\section{Chemical assays}

Hemoglobin, total plasma proteins and serum albumin levels were determined with the aid of commercial kits (Labtest, Belo Horizonte, Brazil). Moisture, protein, and ether extract in the carcass were determined according to $\mathrm{AOAC}^{1}$.

\section{Immunoglobulin determination}

Trypanosome-specific IgG and IgM in serum samples of mice fed on either low or high protein diets were identified by ELISA as described previously ${ }^{6}$.

\section{Histopathological examination}

Tissue samples were fixed in $4 \%$ formaldehyde and processed for paraffin embedding. The histological sections (3-5 $\mu \mathrm{m})$ were stained with hematoxylin-eosin and the slides examined by only one person who did not have access to the codification of the animal. Identification of the samples was done only after each report had already been written.

\section{Statistical analysis}

The results were compared through analysis of variance followed by the determination of the minimal significant difference. ${ }^{21}$ The calculations were made using EPISTAT computer program (T.L. Gustafson, Round Rock, TX, USA).

\section{RESULTS}

\section{Weight evolution}

The effects of protein content in the diet were, initially, monitored by measuring changes in total body weight after administration of the different diets. As expected, low protein levels in the diet induced a decrease in the rate of weight gain in CV mice as compared to that observed in animals fed on normal or high protein diets (Figure 1A). On the other hand, GF mice showed an increase in body weight regardless of the diet (Figure 1B). Injection of the parasite caused a decrease in body weight after one week of infection, both in GF and CV animals, with the exception of CV mice fed on the low protein diet. In this group, no changes in body weight were associated with the infection by $T$. cruzi. 


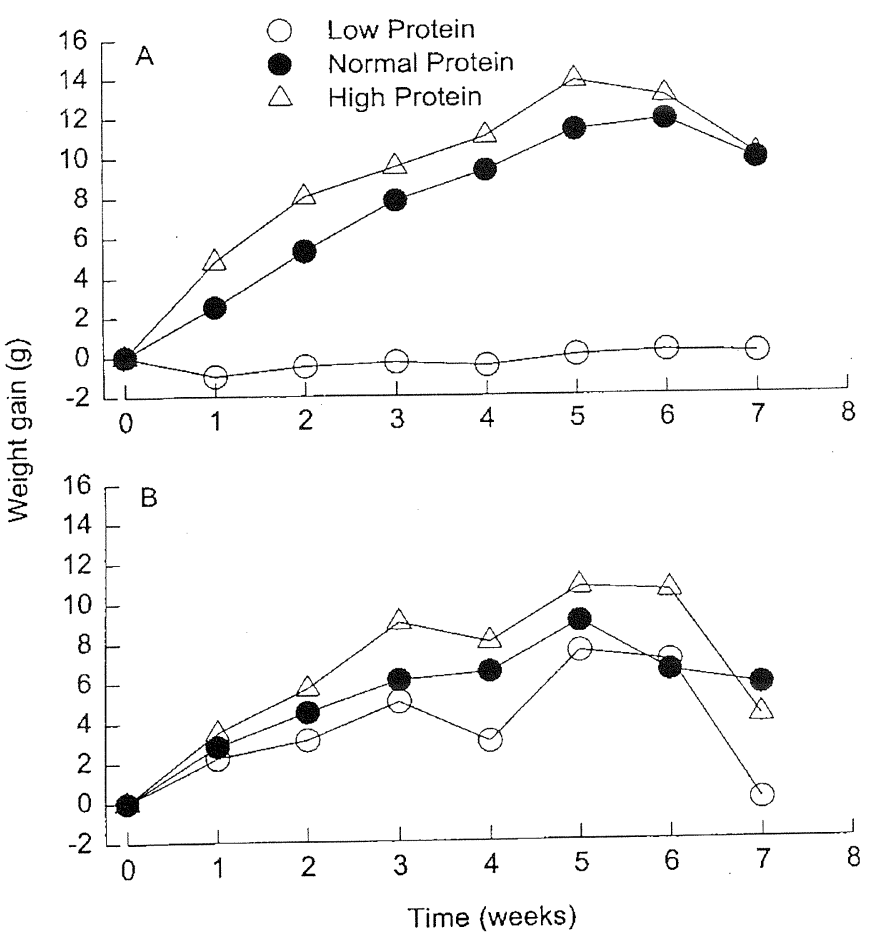

Fig. 1 - Weight gain of conventional (A) and gnotobiotic (B) CFW mice fed on low protein ( $4.4 \%$ of casein) normal protein ( $13.2 \%$ of casein), or high protein $(26.4 \%$ of casein) diets. Each point represents the average of 5 mice. At the 28 th day on the diets, all mice were infected, intraperitoneally, with $5 \times 10^{-3}$ trypomastigotes of Trypanosoma cruzi (CL strain),

\section{Hemoglobin}

Comparison of hemoglobin levels between GF and CV mice showed that this parameter was strongly affected not only by the diet but also by the presence or absence of the microbiota. Thus, GF mice fed on normal protein diet had hemoglobin levels that were lower than those from their $\mathrm{CV}$ counterparts (Table 2). Alteration of the protein content in the diet of GF mice caused an increase in the levels of hemoglobin both in animals fed on low or high protein diets. CV mice, on the other hand, showed a decrease in hemoglobin levels when fed on low protein diet, while showing no alteration with increased protein content intake.

Infection of GF mice with $T$. cruzi caused a general decrease in hemoglobin levels that was more pronounced at the end of the experiment. This decrease was already evident in GF animals on low and high protein diets after two weeks of infection. Curiously, however, this decrease in hemoglobin levels was only observed in $\mathrm{CV}$ animals fed on a normal protein diet; no differences were observed in CV mice fed on the two other diets (Table 2).

\section{Erythrocyte count}

No differences in red blood cells (RBC) count could be detected among the subgroups before infection in GF animals. In the $\mathrm{CV}$ animals, however, the number of RBC was significantly lower in the subgroup fed on a low protein diet when compared to the groups fed on diets containing 13.2 or $26.4 \%$ of protein. In addition, no differences in this parameter could be attributed to the presence or absence of the microbiota before the animals were injected with the parasite.

The effect of the infection with $T$. cruzi on the number of $\mathrm{RBC}$ was dependent not only on the diet but also on the presence of the microbiota. GF mice showed a reduction in $\mathrm{RBC}$ count regardless of the protein intake. On the other hand, this pattern was observed in CV mice only when the animals were fed on a normal protein diet. CV animals fed on high protein diet showed a transient increase in RBC count one week after infection which disappeared after on whereas no changes were observed in the already low counts observed in CV animals fed on a low protein diet (Table 2). The data were in agreement with those obtained for hemoglobin.

\section{Leukocyte levels}

Compared to animals fed on normal protein diets, no changes in leukocyte counts were observed both in $\mathrm{CV}$ and GF animals regardless of the protein intake. In addition, these levels were comparable between GF and CV animals. This pattern was changed after infection. While showing no significant increase in leukocyte numbers when compared to noninfected counterparts, GF animals fed on high protein diet showed higher counts than mice fed on a low protein diet. In CV mice, on the other hand, a distinct rise in the numbers of white blood cells was observed in all groups after 21 days of infection. These levels were also significantly higher than those observed in GF animals submitted to the same dietary regimen (Table 2).

\section{Plasma protein and albumin}

In the GF group, the level of protein in the diet did not affect the levels of total protein and albumin in plasma (Table 2). In the CV group, however, the low protein diet elicited a significant decrease in both those parameters. During the course of infection, a decrease in plasma protein and albumin levels in the GF animals was observed. In the $\mathrm{CV}$ group, the levels of total protein did not change appreciably during the course of infection while the levels of albumin tended to increase in all subgroups.

\section{Water content of the carcass}

No differences were observed in the water content of the carcass amongst GF animals regardless of the diet. In the $\mathrm{CV}$ group, however, a significant increase in the moisture content was observed in animals fed on low protein diet when compared to the other subgroups and also to its GF counterpart. Infection with $T$. cruzi induced an increase in this parameter in all groups with the exception of the GF group fed on normal protein diet, which showed no significant alteration during the course of infection (Table 3). 
CINTRA, I.P.; SILVA, M.E.; SILVA, M.E.C.; SILVA, M.E.; AFONSO, L.C.C.; NICOLI, J.R.; BAMBIRRA, E.A. \& VIEIRA, E.C. - Influence of dietary protein content on Trypanosoma cruzi infection in germfree and conventional mice. Rev. Inst. Med. trop. S. Paulo, 40 (6): 355-362, 1998.

TABLE 2

Hemoglobin levels, red blood cell and leukocyte counts and plasma total protein and albumin in germfree and conventional mice fed on low protein, normal protein, or high protein diets, infected with $5 \times 10^{5}$ trypomastigotes of Trypanosoma cruzi. Data represent mean \pm one standard deviation

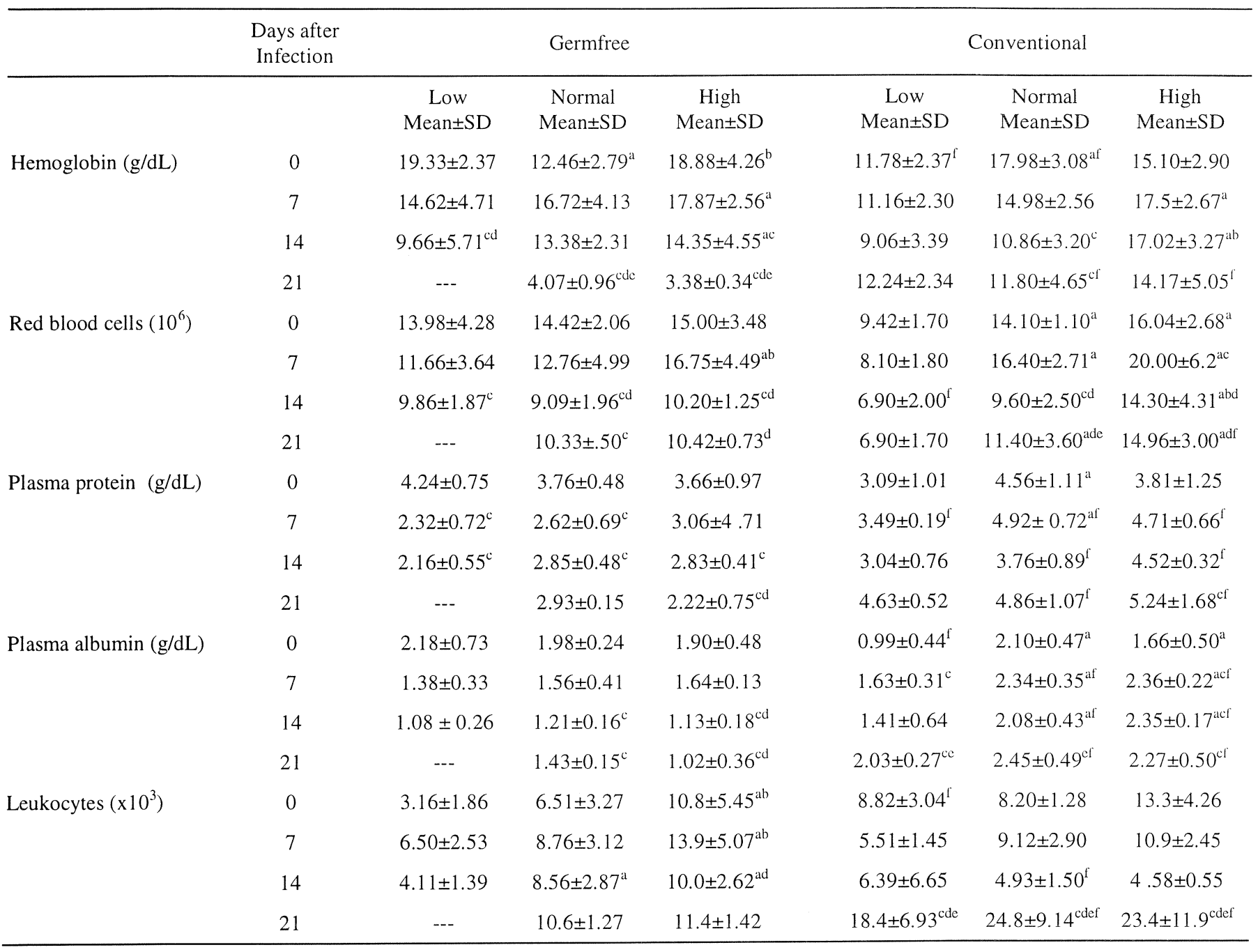

a $\mathrm{p} \leq 0.05$ compared with the group fed on low protein diet

${ }^{\mathrm{b}} \mathrm{p} \leq 0.05$ compared with the group fed on normal protein diet

" $\mathrm{p} \leq 0.05$ compared with zero time

$\mathrm{p} \leq 0.05$ compared with the 7 th day after infection

$\mathrm{p} \leq 0.05$ compared with the 14 th day after infection

$\mathrm{p} \leq 0.05$ compared with the corresponding germfree group

\section{Fat content}

No differences in the values of ether extract were found between the GF and their CV counterparts. As expected, in both groups, fat content was lower in the animals fed on the low protein diet, both in GF and CV animals (Table 3).

After infection, in most of the groups (CV-high protein excluded), an increase of the fat content in the carcass was observed after one week. This tendency was reversed after 14 days in all groups and, with the exception of GF animals on low protein diet, all groups showed a marked decrease in this parameter.

\section{Protein content in the carcass}

$\mathrm{CV}$ animals fed on high and normal protein diets showed a higher protein content in the carcass when compared to mice fed on low protein diet. This difference was maintained during the course of infection regardless of the fact that both normal and high protein subgroups decreased their protein content while no significant changes 
CINTRA, I.P.; SILVA, M.E.; SILVA, M.E.C.; SILVA, M.E.; AFONSO, L.C.C.; NICOLI, J.R.; BAMBIRRA, E.A. \& VIEIRA, E.C. - Influence of dietary protein content on Trypanosoma cruzi infection in germfree and conventional mice. Rev. Inst. Med. trop. S. Paulo, 40 (6): 355-362, 1998.

TABLE 3

Carcass water content, protein (dry weight) and ether extract (dry weight) in germfree and conventional mice fed on low protein, normal protein, or high protein diets, infected with $5 \times 10^{5}$ trypomastigotes of Trypanosoma cruzi. Data represent mean \pm one standard deviation

\begin{tabular}{|c|c|c|c|c|c|c|c|}
\hline & $\begin{array}{l}\text { Days after } \\
\text { infection }\end{array}$ & & Germfree & & & Conventional & \\
\hline \multirow{5}{*}{$\begin{array}{l}\text { Water content in } \\
\text { carcass }(\%)\end{array}$} & & $\begin{array}{c}\text { Low } \\
\text { Mean } \pm \text { SD }\end{array}$ & $\begin{array}{c}\text { Normal } \\
\text { Mean } \pm \text { SD }\end{array}$ & $\begin{array}{c}\text { High } \\
\text { Mean } \pm \text { SD }\end{array}$ & $\begin{array}{c}\text { Low } \\
\text { Mean } \pm S D\end{array}$ & $\begin{array}{c}\text { Normal } \\
\text { Mean } \pm S D\end{array}$ & $\begin{array}{c}\text { High } \\
\text { Mean } \pm S D\end{array}$ \\
\hline & 0 & $59.8 \pm 4.4$ & $65.2 \pm 5.3$ & $60.5 \pm 7.2$ & $67.0 \pm 2.8^{f}$ & $61.4 \pm 0.9^{\mathrm{a}}$ & $64.5 \pm 0.5^{\mathrm{ab}}$ \\
\hline & 7 & $62.3 \pm 2.9$ & $63.9 \pm 2.3$ & $55.4 \pm 10.1^{\mathrm{ab}}$ & $67.5 \pm 1.3^{\mathrm{f}}$ & $64.2 \pm 1.2^{\mathrm{ac}}$ & $68.3 \pm 0.9^{b c f}$ \\
\hline & 14 & $67.1 \pm(2.2)^{\mathrm{c}}$ & $68.7 \pm 1.9$ & $67.0 \pm 7.4^{\mathrm{cd}}$ & $71.9 \pm 0.7^{\mathrm{cdf}}$ & $72.2 \pm 0.8^{\mathrm{cdf}}$ & $71.5 \pm 0.7^{\mathrm{cd}}$ \\
\hline & 21 & --- & $69.7 \pm 3.1$ & $69.4 \pm 2.4^{\mathrm{cd}}$ & $70.5 \pm 1.4^{\mathrm{cd}}$ & $71.2 \pm 1.8^{\mathrm{cd}}$ & $69.8 \pm 1.4^{\mathrm{ce}}$ \\
\hline \multirow{2}{*}{$\begin{array}{l}\text { Ether extract in } \\
\text { carcass }(\%)\end{array}$} & 0 & $11.9 \pm 3.6$ & $20.8 \pm 7.9^{\mathrm{a}}$ & $13.7 \pm 4.8$ & $8.5 \pm 4.5$ & $19.7 \pm 4.3^{\mathrm{a}}$ & $13.0 \pm 1.5^{\mathrm{ab}}$ \\
\hline & 7 & $21.2 \pm 6.1^{\mathrm{c}}$ & $17.9 \pm 5.8$ & $21.3 \pm 4.6$ & $9.3 \pm 2.8^{f}$ & $17.4 \pm 3.0^{\mathrm{a}}$ & $8.8 \pm 1.5^{\mathrm{bcr}}$ \\
\hline \multirow{6}{*}{$\begin{array}{l}\text { Protein content in } \\
\text { carcass }(\%)\end{array}$} & 14 & $12.8 \pm 3.6^{\mathrm{d}}$ & $10.0 \pm 5.7^{\mathrm{cd}}$ & $10.4 \pm 10.6^{\mathrm{d}}$ & $4.1 \pm 1.6^{\mathrm{cdt}}$ & $3.5 \pm 1.9^{\mathrm{cdf}}$ & $3.0 \pm 1.3^{\mathrm{cd}}$ \\
\hline & 21 & -- & $9.0 \pm 4.6^{\mathrm{cd}}$ & $2.8 \pm 0.5^{\mathrm{cde}}$ & $5.5 \pm 2.3^{\mathrm{d}}$ & $4.4 \pm 1.7^{\mathrm{cd}}$ & $3.3 \pm 1.8^{\mathrm{cd}}$ \\
\hline & 0 & $73.4 \pm 3.7$ & $76.8 \pm 6.9$ & $74.0 \pm 8.0$ & $68.7 \pm 2.4^{\mathrm{f}}$ & $73.4 \pm 3.1^{\mathrm{a}}$ & $76.4 \pm 3.8^{\mathrm{a}}$ \\
\hline & 7 & $72.5 \pm 5.5$ & $77.8 \pm 6.8$ & $70.3 \pm 6.0^{\mathrm{b}}$ & $68.4 \pm 2.0$ & $76.0 \pm 1.5^{\mathrm{a}}$ & $76.0 \pm 1.4^{\mathrm{a}}$ \\
\hline & 14 & $66.9 \pm 1.2^{\mathrm{c}}$ & $68.8 \pm 6.0^{\mathrm{cd}}$ & $69.0 \pm 4.4$ & $67.7 \pm 4.6$ & $71.4 \pm 2.7^{\mathrm{ad}}$ & $74.0 \pm 0.5^{\mathrm{ar}}$ \\
\hline & 21 & --- & $67.1 \pm 0.7^{\mathrm{cd}}$ & $66.3 \pm 1.4^{\mathrm{c}}$ & $66.2 \pm 1.1$ & $70.4 \pm 2.2^{\mathrm{acd} f}$ & $72.1 \pm 0.4^{\mathrm{acdf}}$ \\
\hline
\end{tabular}

a $\mathrm{p} \leq 0.05$ compared with the group fed on low protein diet

" $p \leq 0.05$ compared with the group fed on normal protein diet

" $\mathrm{p} \leq 0.05$ compared with zero time

" $\mathrm{p} \leq 0.05$ compared with the 7 th day after infection

: $\mathrm{p} \leq 0.05$ compared with the 14 th day after infection

i $\mathrm{p} \leq 0.05$ compared with the corresponding germfree group

were observed in the low protein group. On the other hand, in the GF mice, the protein level in the diet did not affect the protein content in the carcass. After the infection, a decrease in this parameter was observed in all dietary subgroups (Table 3 ).

\section{Parasitemia}

Figure 2 shows the parasitemia curves of $\mathrm{CV}$ and GF mice. Parasite levels in CV animals fed on normal or high protein diets were similar throughout the infection with a maximum number around $2.5 \times 10^{4}$ parasites $/ 5 \mathrm{~mm}^{3}$ being observed after three weeks of infection. On the other hand, CV mice that received high levels of protein showed a marked increase in parasitemia. This increase was already evident after 14 days of infection and persisted untill the end of the experiment when around $5.0 \times 10^{4}$ parasites $/ 5 \mathrm{~mm}^{3}$ could be observed.

When GF mice were injected with the parasite, a different pattern in the parasitemia curve was observed. While the same differences seen in $\mathrm{CV}$ mice between normal and high protein diets were still observed in GF animals belonging to these groups, a marked increase in parasitemia was detected in GF mice fed on low proteic diet. As much as $9.0 \times 10^{4}$ parasites $/ 5 \mathrm{~mm}^{3}$ of blood could be detected in these animals at the 17 th day of infection compared to $1.5 \times 10^{4}$ observed in the normal protein group.

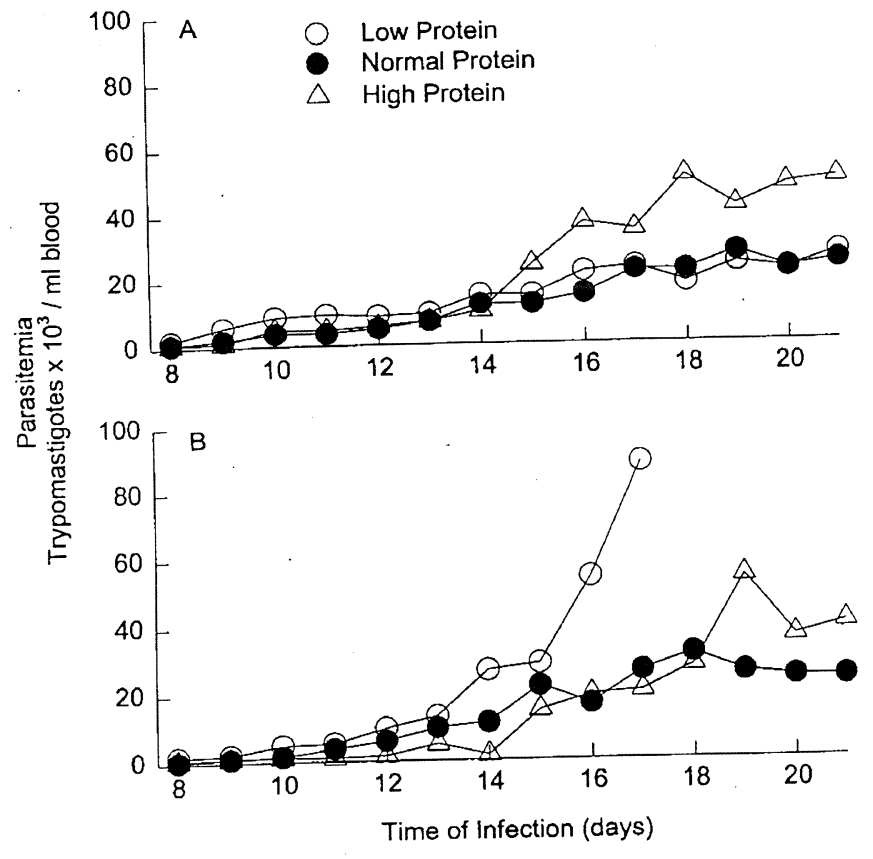

Fig. 2 - Parasitemia of conventional (A) and gnotobiotic (B) CFW mice fed on low protein $(4.4 \%$ of casein) normal protein $(13.2 \%$ of casein), or high protein $(26.4 \%$ of casein) diets, infected, intraperitoneally, with $5 \times 10^{-3}$ trypomastigotes of Trypanosoma cruzi (CL strain). Each point represents the average of five mice. 
CINTRA, I.P.; SILVA, M.E.; SILVA, M.E.C.; SILVA, M.E.; AFONSO, L.C.C.; NICOLI, J.R.; BAMBIRRA, E.A. \& VIEIRA, E.C. - Influence of dietary protein content on Trypanosoma cruzi infection in germfree and conventional mice. Rev. Inst. Med. trop. S. Paulo, 40 (6): 355-362, 1998.

\section{Immunoglobulins}

The effects of the microbial and nutritional status on the immune system during infection were analyzed by measurement of $T$. cruzi specific IgG and IgM levels on the sera of infected animals. IgG levels specific to the epimastigote stage of the parasite were measured on the sera of animals fed on low and high protein diets at 7 and 14 days after infection. The results (Table 4) show that GF animals fed on low protein diet had lower levels of specific IgG than their high protein diet counterpart. The same was observed in $\mathrm{CV}$ mice but only at a later time point in infection.

When sera were assayed for specific IgM levels (Table 4), it could be shown that the nutritional status affected only the CV animals. These mice showed reduced levels of specific IgM when submitted to low protein intake. GF mice, on the other hand, were not affected by the diet with regard to the level of specific IgM. However, when compared to their CV counterparts, much higher levels of this immunoglobulin were detected in the sera of infected animals, especially at two weeks of infection.

\section{Histopathology}

Cellular and tissue parasitism was much more intense in GF than in $\mathrm{CV}$ mice. Within the GF and CV groups, no difference due to the nutritional treatments was detected.

\section{DISCUSSION}

These results show that the protein need of GF mice is much lower than that of the CV ones. Similar results had been reported for rats in an oral communication by GUSTAFSSON ${ }^{9}$. After four weeks on low protein diet, the GF mice put on $21 \%$ of weight whereas no weight gain in the same period could be observed in the CV counterparts. The protein deficiency affected less the GF than the
CV mice as revealed by the levels of hemoglobin, red blood cells, total plasma protein, and plasma albumin (Table 2). Apparently, part of the protein ingested is used by the intestinal microbiota. The initial weights of CV mice were lower than those of the GF group. However, the final weights were nearly the same for both groups.

GAZZINELLI et al. reported higher weight gain in GF than in $\mathrm{CV}$ mice fed on control diet. However, sucrose-rich diets produced higher weight gain in CV mice when compared with their GF counterparts. Carcass weight, moisture, lipid and protein content were the same for both $\mathrm{CV}$ and GF mice fed on control diets. High sucrose concentration (20 and 40\%) in the diet produced higher content in all these parameters in $\mathrm{CV}$ than in GF mice ${ }^{7}$.

Recently, LHOSTE et al., feeding rats with diets containing 22 and $45 \%$ of protein, found a lower consumption index (feed intake/ weight gain) in GF than in CV rats. The weight gain was the same for both groups but the GF rats ate less ${ }^{11}$.

As expected, the hemoglobin levels were lower in both groups of mice fed on low protein diet. After infection, the levels of hemoglobin, red blood cells and plasma protein were significantly lower in GF than in CV mice (Table 2). This may be explained by the fact that the disease is more severe in the GF group. After 21 days of infection, the leukocytosis was more pronounced in the $\mathrm{CV}$ than in the GF mice (Table 2). The delay in reaction of GF animals may account for this result. There was no appreciable difference in the water content in the carcass between GF and CV animals. In general, the lipid content in the carcass was higher in GF than in CV animals. With the progress of infection, the lipid content decreased in both groups of mice (Table 3 ). As a result, the protein content was increased in the course of infection.

The results obtained here confirm previous findings which showed that Chagas' disease is more severe in GF than in CV mice. ${ }^{19}$ The tissue injury was much more intense in the GF than in the CV

TABLE 4

Epimastigote-specific $\operatorname{IgG}$ and $\operatorname{IgM}$ serum levels of conventional (CV) and germfree (GF) mice fed on low or high protein diets and infected with CL strain of Trypanosoma cruzi. Mice were infected intraperitoneally with $5 \times 10^{5}$ blood form trypomastigotes after 28 days on diets and sacrificed after 7 and 14 days after infection. Antibody levels were determined by ELISA and the results reported as absorbance at $492 \mathrm{~nm}$. Data are reported as means \pm one standard deviation for five mice per group.

\begin{tabular}{llcccc}
\hline Group & Diet & \multicolumn{2}{c}{ IgG } & & IgM \\
& & \multicolumn{2}{c}{ Days after infection } & Days after infection \\
\cline { 3 - 6 } & & 7 & 14 & 7 & 14 \\
\hline GF & low protein & $0.793 \pm 0.128^{\mathrm{a}}$ & $0.504 \pm 0.144^{\mathrm{a} *}$ & $0.439 \pm 0.207^{*}$ & $1.105 \pm 0.138^{*}$ \\
& high protein & $1.311 \pm 0.688^{*}$ & $1.473 \pm 0.764^{*}$ & $0.596 \pm 0.077$ & $1.345 \pm 0.617^{*}$ \\
CV & low protein & $0.808 \pm 0.204$ & $1.060 \pm 0.309^{\mathrm{a}}$ & $0.157 \pm 0.043^{\mathrm{a}}$ & $0.471 \pm 0.206^{\mathrm{a}}$ \\
& high protein & $1.079 \pm 0.183$ & $1.985 \pm 0.514$ & $0.456 \pm 0.098$ & $0.801 \pm 0.132$ \\
\hline
\end{tabular}

"statistical difference ( $\leq 0.05)$ between nutritional groups with the same microbial status (CV or GF) and day of infection

* statistical difference ( $p \leq 0.05$ ) between $C V$ and GF groups with the same nutritional status (low protein or high protein diets) and day of infection 
CINTRA, I.P.; SILVA, M.E.; SILVA, M.E.C.; SILVA, M.E.; AFONSO, L.C.C.; NICOLI, J.R.; BAMBIRRA, E.A. \& VIEIRA, E.C. - Influence of dietary protein content on Trypanosoma cruzi infection in germfree and conventional mice. Rev. Inst. Med. trop. S. Paulo, 40 (6): $355-362,1998$.

group. This may be explained by the immaturity of the immune system of GF animal. ${ }^{17}$ Since T. cruzi is very virulent, it takes advantage of the naive cellular immune system of the animal. No important differences caused by the nutritional insult could be detected neither in the GF nor in the CV mice. Explanations for that could be: (a) The protein need of GF animal is lower; (b) Since there was no prevention of coprophagy, the CV mice could have satisfied, partially, by this means, its protein need. Our results confirms those of CARLOMAGNO et al. who, studying infection with $T$. cruzi in mice submitted to severe or moderate calorie deficiency, reported that the histopathological alterations were not dependent on the diet ${ }^{4}$.

The reactions to nutritional insult and to infection with $T$. cruzi of GF and CV mice were different. The absence of microbial flora elicits many local and distant modifications that affects all the organs and systems of the animal.

The levels of parasitemia were nearly the same for both GF and $\mathrm{CV}$ groups fed on normal or high protein diets. However, on low protein diet the parasitemia was less pronounced in both groups, more evidently in the CV group. The protein deficiency may have affected negatively the development of the parasite.

The effect of moderately and severely calorie deficient diets on the course of T. cruzi infection with 500 or 50 trypomastigotes was studied in Balb/c mice ${ }^{4}$. Onset of parasitemia was observed earlier in severely or moderately malnourished mice when compared with the controls. Survival time was significantly shorter for severely malnourished animals regardless of the infecting dose. All moderately malnourished animals died, as well as the control animals, on infection with 500 trypomastigotes. On inoculation with 50 trypomastigotes, $33 \%$ of the control mice survived whereas the severely or moderately malnourished mice died ${ }^{4}$.

GOMES et al. ${ }^{8}$ used four levels of protein (soybean supplemented with methionine) in the diets: $4.75,9.5,15.25$, and $19 \%$ and infected adult mice with either $\mathrm{CL}$ or $\mathrm{Y}$ strain of $T$. cruzi. The parasitemia and the mortality were significantly higher in the group fed on diet containing the lowest protein level. The parasite frequency in muscle cells was higher in mice on severe protein deficiency even though the inflammatory lesions were less extensive in this group when compared with the others. It should be pointed out that these authors worked with adult mice whereas, in the present paper, weaning mice were used. The latter are more sensitive to both nutritional insult and to infection.

The immunoglobulin analyses showed that in relation to the microbial status, GF animals had a higher response during the acute phase of trypanosome-specific IgM and lower for IgG, independently of the nutritional status. In general, the effects of protein malnutrition on humoral immunity are expected to be less severe than that on cell-mediated immunity. B cell numbers and immunoglobulin levels are not affected significantly but the antibody response may vary with the antigen and the form it is presented ${ }^{22}$.

It may be concluded that the protein deficiency affected more intensively the $\mathrm{CV}$ mice than their GF counterparts, according to several nutritional parameters. As far as the protein nutritional status, the protein deficiency aggravated the infection with $T$. cruzi according to biochemical and physiological parameters even though the histopathological findings revealed differences related to the microbiological status and not to the protein nutritional status.

\section{RESUMO}

\section{Influência do conteúdo em proteína na ração sobre a infecção por Trypanosoma cruzi em camundongos sem germes e convencionais}

Camundongos isentos de germes (GF) e convencionais (CV) foram alimentados com rações contendo 4,4, 13,2 ou 26,4\% de proteína (peso/peso). Os camundongos CV alimentados com ração baixa em proteína não ganharam peso durante quatro semanas, enquanto a ração deficiente em proteína não afetou o crescimento dos camundongos GF. Após quatro semanas nessas rações, os camundongos foram inoculados com $5 \times 10^{3}$ tripomastigotos de Trypanosoma cruzi. A deficiência em proteína afetou menos os camundongos GF do que os CV, segundo os seguintes parâmetros: ganho em peso, hemoglobina, níveis em proteína e albumina no plasma e conteúdos em água e proteína na carcassa. A infecção com $T$. cruzi produziu um decréscimo significante nos níveis em hemoglobina, na contagem de células vermelhas sanguíneas e nos conteúdos em água e proteína na carcassa. Este descréscimo foi mais acentuado nos camundongos GF. Histopatologicamente, não houve diferença entre os tratamentos nos animais com o mesmo estatuto microbiológico (GF ou CV). Contudo, a doença foi mais grave nos camundongos $\mathrm{GF}$ do que nos $\mathrm{CV}$.

\section{ACKNOWLEDGEMENTS}

This work was supported by Financiadora de Estudos e Projetos (FINEP), Conselho Nacional de Desenvolvimento Científico e Tecnológico (CNPq), Fundação de Amparo à Pesquisa do Estado de Minas Gerais (FAPEMIG), and Pró-Reitoria de Pesquisa da UFMG (PRPq-UFMG). The technical help of Ronilda Maria de Paula, Maria Helena de Oliveira, and Antonio Mesquita Vaz is greatly acknowledged.

\section{REFERENCES}

1. A.O.A.C. ASSOCIATION OF OFFICIAL ANALYTICAL CHEMISTS Official methods of Analysis. 13. ed. Washington, AOAC, 1980

2. BRENER, Z. - Therapeutic activity and criterion of cure on mice experimentally infected with Trypanosoma cruzi. Rev. Inst. Med. trop. S. Paulo, 4: 389 $396,1962$.

3. BRENER, Z. \& CHIARI, E. - Variações morfológicas observadas em diferentes amostras de Trypanosoma cruzi. Rev. Inst. Med. trop. S. Paulo, 5: 220-224, 1963.

4. CARlomagno, M.A.; Riarte, A.; MORENO, M. \& SEGURA, E.L. Effects of calorie restriction on the course of Trypanosoma cruzi infection. Nutr. Res, 7: 1031-1040, 1987. 
CINTRA, I.P.; SILVA, M.E.; SILVA, M.E.C.; SILVA, M.E.; AFONSO, L.C.C.; NICOLI, J.R.; BAMBIRRA, E.A. \& VIEIRA, E.C. - Influence of dietary protein content on Trypanosoma cruzi infection in germfree and conventional mice. Rev. Inst. Med. trop. S. Paulo, 40 (6): 355-362, 1998.

5. CINTRA, I.P.; SILVA, M.E.C.; SILVA, M. E. et al. - Influence of dietary protein content on the evolution of Chagas' disease in germfree and conventional mice. Microecol. Ther., 20: 459-463, 1990.

6. FURARAH, A.M.; CROCCO-AFONSO, L.C.; SILVA, M.E.C. et al. - Immune responses of germfree mice to experimental infection with Trypanosoma cruzi. Braz. J. med. biol. Res., 24: 1223-1231, 1991.

7. GAZZINELLI, R.T.; SILVA, M.E.; MORAES-SANTOS, T.; NICOLI, J.R. \& VIEIRA, E.C. - Effect of high sucrose diets on carcass composition in conventional and germfree mice. Arch. lat.-amer. Nutr., 42: 539-545, 1992.

8. GOMES, N.G.L.; PEREIRA, F.E.L.; DOMINGUES, G.C.S. \& ALVES, J.R. Effects of severe protein restriction in levels of parasitemia and in mortality of mice accutely infected with Trypanosoma cruzi. Rev. Soc. bras. Med. trop., 27: 19-24, 1994.

9. GUSTAFSSON, B.E. - Introduction of specific microorganisms into germfree animals. In: WOLSTENHOLME, G.E.W. \& O'CONNOR, M., ed. Nutrition and infection. Boston, Little Brown, 1974. p. 16. (Ciba Study group no. 31).

10. KEUSCH, G.T. \& FARTHING, M.J.G. - Nutrition and infection. Ann. Rev. Nutr., 6: 131-154, 1986.

11. LHOSTE, E.F.; CATALA, I.; FISZLEWICZ, M. et al. - Influence of caecal microflora and of two dietary protein levels on the adaptation of the exocrine pancreas; comparative study in germ-free and conventional rats. Brit. J. Nutr., 75: 433-444, 1996.

12. MACHADO, C.R.; MORAES-SANTOS, T. \& MACHADO, A.B.M. - Cardiac noradrenalin in relation to protein malnutrition in chronic experimental Chagas' disease in the rat. Amer. J. trop. Med. Hyg., 33: 835-838, 1984.

13. MORAES-SANTOS, T.; NICOLI, J.R.; SILVA, M.E. \& VIEIRA, E.C. - A method for steam-sterilizing semi-solid diets for germfree mice research. Arch. lat.-amer. Nutr., 41: 546-554, 1991.

14. PEDROSA, M.L.; SILVA, M.E.; SILVA, M.E. et al. - The effect of iron deficiency and iron overload on the evolution of Chagas' disease produced by three strains of Trypanosoma cruzi in CFW mice. Comp. Biochem. Physiol., 97A: 235-243, 1990.
15. PEDROSA, M.L.; NICOLI, J.R.; SILVA, M.E. et al. - The effect of iron nutritional status on Trypanosoma cruzi infection in germfree and conventional mice. Comp. Biochem. Physiol., 106A: 813-821, 1993.

16. PLEASANTS, J.R. - Gnotobiotics. In: MELBY Jr., E.C. \& ALTMAN, N.H., ed. CRC handbook of laboratory animal science. Cleveland, CRC Press, 1974. p 119-174.

17. ROGERS, T.Y. \& BALISH, E. - Effect of the systemic candidiasis on blastogenesis of lymphocytes from germfree and conventional rats. Infect. Immun., 20: 142-150, 1978.

18. SANTOS, C.F.; SILVA, M.E.; EVANGELISTA, E.A. et al. - Effect of essential fatty acid deficient diet on experimental infection with Trypanosoma cruzi in germfree and conventional mice. Braz. J. med. biol. Res., 25: 795 803,1992

19. SILVA, M.E.; EVANGELISTA, E.A.; NICOLI, J.R.; BAMBIRRA, E.A. \& VIEIRA, E.C. - American trypanosomiasis (Chagas' disease) in conventional and germfree rats and mice. Rev. Inst Med. trop. S. Paulo, 29: $284-288,1987$

20. SILVA, M.E.; SILVA, M.E.C.; SILVA, M.E. et al. - Vitamin D overload and experimental Trypanosoma cruzi infection: parasitological and histopathological aspects. Comp. Biochem. Physiol., 104A: 175-181, 1993.

21. SNEDECOR, G.W. \& COCHRAN, W.G. - One-way classification. Analysis of variance. In: SNEDECOR, G.W. \& COCHRAN, W.G. Statistical methods. 7 ed. Ames, Iowa State University Press, 1980. p 215-277.

22. TERR, A.I.; DUHEY, D.P.; YUNIS, E.J.; SLAVIN, R.G. \& WALDMAN, R.H - Physiologic and environmental influences on the immune system. In: STITES, D.P. \& TERR, A.I., ed. Basic and clinical immunology. Norwack, Appleton and Lange, 1991.p 187-199.

23. TREXLER, P.C. - The use of plastics in the design of isolator systems. Ann. N.Y. Acad. Sci., 78: 29-36, 1959.

24. VIEIRA, E.C.; NICOLI, J.R.; MORAES-SANTOS, T. et al. - Cutaneous leishmaniasis in germfree, gnotobiotic, and conventional mice. Rev. Inst. Med. trop. S. Paulo, 29: 385-387, 1987.

25. YAEGER, R.G. \& MILLER, O.N. - Effect of lysine deficiency on Chagas' disease in laboratory rats. J. Nutr., 81: 169-179, 1963

Received: 21 May 1998

Accepted: 09 October 1998 